Quim. Nova, Vol. 33, No. 3, 644-648, 2010

\title{
BIOACCUMULATION OF METALS IN AQUATIC INSECTS OF STREAMS LOCATED IN AREAS WITH SUGAR CANE CULTIVATION
}

\author{
Juliano José Corbi* e Claudio Gilberto Froehlich \\ Departamento de Biologia, Faculdade de Filosofia Ciências e Letras de Ribeirão Preto, Universidade de São Paulo, Av. Bandeirantes, \\ 3900, 14040-901 Ribeirão Preto - SP, Brasil \\ Susana Trivinho Strixino \\ Departamento de Hidrobiologia, Universidade Federal de São Carlos, CP 676, 13560-970 São Carlos - SP, Brasil \\ Ademir dos Santos \\ Departamento de Química Analítica, Instituto de Química de Araraquara, Universidade Estadual Paulista, CP 355, 14800-970 \\ Araraquara - SP, Brasil
}

Recebido em 6/5/09; aceito em 29/9/09; publicado na web em 23/2/10

\begin{abstract}
Streams located in areas of sugar cane cultivation receive elevated concentrations of metal ions from soils of adjacent areas. The accumulation of metals in the sediments results in environmental problems and leads to bioaccumulation of metal ions by the aquatic organisms. In the present study, bioaccumulation of the metals ions $\mathrm{Al}, \mathrm{Cd}, \mathrm{Cr}, \mathrm{Cu}, \mathrm{Fe}, \mathrm{Mg}, \mathrm{Mn}$ and $\mathrm{Zn}$ in aquatic insects in streams impacted by the sugar cane was evaluated. The results pointed out that the insects were contaminated by the sediment and that the collector organisms as Chironomus species accumulated higher concentration of metals than the predator organisms.
\end{abstract}

Keywords: metals; bioaccumulation; trophic transfer.

\section{INTRODUCTION}

The use of fertilizers containing different concentrations of metals such as lead, nickel, chromium, cadmium, aluminum and zinc in different periods of cultivation of sugar cane, in addition to the deforestation of riparian vegetation, cause impacts on the hydric resources of the adjacent areas, leading to contamination of the aquatic sediments. ${ }^{1,2}$ Metals introduced in the aquatic environment by the sugar cane activity can be absorbed and incorporated into the sediments ${ }^{3,4}$ and in the food chains. ${ }^{5-7}$ In general, these impacts have been caused by the absence of riparian vegetation, which is responsible for absorption of toxic products, which come from the neighboring cultivated areas. ${ }^{1,8-11}$ Every year, sugar cane cultivation, using fertilizers is carried out. This process causes severe damages to the aquatic communities. Moreover, heavy metals as $\mathrm{Cd}$ can be bioaccumulated in the organisms, magnified in the food chain, threatening human health. ${ }^{12}$

Metal accumulation in the sediments results in serious environmental problems to the surrounding areas, affecting water quality, bioassimilation and bioaccumulation of metals by the aquatic organisms. ${ }^{13,14}$ Sediments may contribute significantly to increase concentrations of metals in aquatic invertebrates, either by absorption/ adsorption from interstitial water or directly by ingestion. ${ }^{15}$ In aquatic systems, the levels of metals in the aquatic sediments and in some aquatic predator organisms were generally higher in streams in sugar cane areas than in streams located in preserved areas. ${ }^{2}$ The accumulation of metals in the sediments and the contamination of the aquatic invertebrates represent an unsafe link for the transference of metals to upper trophic levels, as fishes, reptiles, birds and mammals. ${ }^{16,17}$

All aquatic invertebrates accumulate trace metals even if these metals are not essential to their metabolism. ${ }^{17}$ Aquatic insects can accumulate metals directly from the sediments or by food ingestion and, for such reasons, some species can accumulate more metals than other ones, based in their life cycle. ${ }^{18}$ When transferred through macroinvertebrate food webs, vertical (trophic level) and horizontal (diet at any

\footnotetext{
*e-mail: julianocorbi@yahoo.com.br
}

given trophic level) position can be considered as important factors for determining metal concentrations in tissues of different species. Horizontal trophic position, i.e., differences in diet within a trophic level, may be an important determinant of metal concentrations. Therefore, metal bioaccumulation in an organism depends on the species. ${ }^{19}$

Streams located in impacted areas with sugar cane cultivation are generally depauperate in relation to the richness of aquatic macroinvertebrates. ${ }^{20}$ Consequently, some aquatic organisms as bivalves, crustaceans and oligochaetes, commonly used as biomonitors of metal contamination, are hard to be collected, restricting their appliance. In contrast, some aquatic insects like Chironomus species (Chironomidae) and Odonata larvae are abundant and tolerate a wide range of chemical, physical and biological conditions in freshwater systems, especially in the streams located in areas with sugar cane cultivation. Moreover, the use of larval insects as biomonitors is facilitated by the fact that the contaminant concentrations are not subjected to the confounding effects of a reproductive cycle or differences between sexes. ${ }^{21}$ For these reasons, aquatic insects can be applied as a useful tool to detect metal contamination and to evaluate, in more detail, the process of the trophic transference of metals in streams.

The scope of the present study is to assess the bioaccumulation of $\mathrm{Al}, \mathrm{Cd}, \mathrm{Cr}, \mathrm{Cu}, \mathrm{Fe}, \mathrm{Mg}, \mathrm{Mn}$ and $\mathrm{Zn}$ from the sediment to some species of aquatic insects in three streams historically impacted (more than 15 years) by metals from fertilizers. The trophic transfer of those metals in organisms inhabiting different trophic levels, as collectors and predators were studied. We have the hypothesis that the collectors and benthic organisms, which live closer to the sediment, accumulate higher concentrations of metals than predator species. These three streams have been studied since 2002, and were chosen because of the possibility of collection of the organisms in great quantities and continuously.

\section{EXPERIMENTAL}

\section{Study sites}

All streams were located on Jacaré-Guaçu river basin, situated in the State of São Paulo, Brazil (Table 1). The three streams are of low 
order, have low water velocity $(<1 \mathrm{~m} / \mathrm{s})$, small depth $(<0,8 \mathrm{~m})$ and width $(<1,5 \mathrm{~m})$ and are located at low altitude, from 500 to $700 \mathrm{~m}$. They are located in the areas of Cerrado and have predominantly sand substrates (fine and coarse, $70 \%$ of the total). ${ }^{21}$ Values of dissolved oxygen varied from 5.3 to $6.8 \mathrm{mg} / \mathrm{L}$ and $\mathrm{pH}$ varied from 5.85 to 6.05 . The average annual precipitation in the Jacaré-Guaçu river basin is of about $1400 \mathrm{~mm} .{ }^{20}$ The wet season occurs between October and March, while the dry season occurs from April to September. Sites are located in extensive areas with sugar cane cultivation, without riparian vegetation. All streams are free from other anthropogenic impacts such as industrial, domestic or mining activities. ${ }^{20}$

Table 1. General characteristics of the three sampling sites, showing the land use types, city and geographic coordinates

\begin{tabular}{lcccc}
\hline Legend & Stream & City & Land use & Coordinates \\
\hline \multirow{2}{*}{ S1 } & Água Sumida & Araraquara & \multirow{2}{*}{ Sugar can } & $21^{\circ} 56^{\prime}(\mathrm{S})$ \\
& & & $48^{\circ} 16^{\prime}(\mathrm{W})$ \\
S2 & São João & Guarapiranga & Sugar cane & $21^{\circ} 57^{\prime}(\mathrm{S})$ \\
& & & $48^{\circ} 15^{\prime}(\mathrm{W})$ \\
\multirow{2}{*}{ S3 } & Água Preta & Ribeirão & \multirow{2}{*}{ Sugar cane } & $22^{\circ} 00^{\prime}(\mathrm{S})$ \\
& & Bonito & & $48^{\circ} 12^{\prime}(\mathrm{W})$ \\
\hline
\end{tabular}

\section{Sampling and storage}

Sediments for metals analyses (Al, Cd, $\mathrm{Cr}, \mathrm{Cu}, \mathrm{Fe}, \mathrm{Mg}, \mathrm{Mn}$ and $\mathrm{Zn}$ ) were sampled, in triplicate, from the three sites using a standard EkmanBirge grab with a sampling area of $255 \mathrm{~cm}^{2}$. Samples were taken twice at each site, from April to July 2008. Sediments were stored at $4{ }^{\circ} \mathrm{C}$ until testing. Larvae of aquatic insects for metals analyses $(\mathrm{Al}, \mathrm{Cd}, \mathrm{Cr}, \mathrm{Cu}$, $\mathrm{Fe}, \mathrm{Mg}, \mathrm{Mn}$ and $\mathrm{Zn}$ ) were collected using a $\mathrm{D}$-frame ${ }^{22}$ aquatic net (mesh sieve $250 \mu \mathrm{m}$ ) and sampled exhaustively until there were enough biomass (at least $0.10 \mathrm{~g}$ ) for laboratory analysis. Larvae of insects retained in the net were transferred to acid-washed polypropylene bags and stored in ice during transportation to the laboratory. In order to study the content of metals in the tissue of the insects, one section of the experiment involved elimination of the gut contents of live larvae $24 \mathrm{~h}$ before carrying out metal analyses. ${ }^{19}$ All insects larvae were microscopically analyzed to verify the complete elimination of the gut content. Then, they were identified and frozen at $-20^{\circ} \mathrm{C}$ in order to perform the metal analyses. ${ }^{18}$ Due to the importance of the amount of organic matter of the sediment in the metal absorption in the aquatic system, ${ }^{23}$ three sediment sub-samples were collected from the streams for organic matter determination.

\section{Analytical procedures}

For analytical analysis, deionized double distilled water (DDDW) was used. All acids were purchased from Merck ${ }^{\circledR}$ (analytical grade). All glass materials were cleaned with concentrated nitric acid as described before. ${ }^{24}$

Sediment samples for metal determination were dried at $65{ }^{\circ} \mathrm{C}$ on glass dishes, homogenized with mortar and pestle. Each of the weighted samples, with approximately $5.0 \mathrm{~g}$, were taken to $100 \mathrm{~mL}$ beakers, to which $5.0 \mathrm{~mL}$ of $\mathrm{HNO}_{3}$ was added and digested to near dryness at $90{ }^{\circ} \mathrm{C}$ on a hot plate. The digested samples were filtered through filter papers and collected in $100 \mathrm{~mL}$ beakers. The filter papers were washed with ca. $20 \mathrm{~mL}$ of distilled water and the contents of the beakers were transferred to $100 \mathrm{~mL}$ volumetric flasks. The resultant solutions were analyzed for metals in a Pye Unicam flame atomic absorption spectrophotometer (Perkin Elmer AAnalyst 300). Digestion and detection were undertaken in triplicate. ${ }^{25}$

Frozen insects larvae were thawed at room temperature. Larvae were pooled to obtain at least $0.10 \mathrm{~g}$ of dry weight. The larvae were taken to a $100 \mathrm{~mL}$ beaker, in which $5.0 \mathrm{~mL}$ of $\mathrm{HNO}_{3}$ was added and digested to near dryness at $90{ }^{\circ} \mathrm{C}$ on a hot plate. Digested samples were cooled at room temperature, filtered by using filter papers and collected in $50 \mathrm{~mL}$ beakers. The filter papers were washed with ca. $20 \mathrm{~mL}$ of water and the contents of the beakers were transferred to 50 $\mathrm{mL}$ volumetric flasks. Pooled samples were analyzed by inductively coupled plasma-atomic emission spectrometry (ICP-AES) (Thermo Jarrel, Ash Iris/ApDuo). Digestion and detection were undertaken in triplicate. ${ }^{18}$ The detection limits were: $\mathrm{Al}-0,002 \mathrm{mg} \mathrm{L}^{-1}$; Cd - 0,0002 $\mathrm{mg} \mathrm{L}^{-1} ; \mathrm{Cr}-0,001 \mathrm{mg} \mathrm{L}^{-1} ; \mathrm{Cu}-0,001 \mathrm{mg} \mathrm{L}^{-1} ; \mathrm{Fe}-0,001 \mathrm{mg} \mathrm{L}^{-1} ; \mathrm{Mg}$ - 0,0001 mg L-1; Mn - 0,0005 mg L-1; Zn - 0,0004 mg L-1.

Organic matter was determined by mass loss after ignition ( 550 ${ }^{\circ} \mathrm{C}, 4 \mathrm{~h}$ ) in dry fractions of sediments (dried in a stove at $60{ }^{\circ} \mathrm{C}$ for $12 \mathrm{~h}$ ), in accordance with the techniques described in the literature. ${ }^{26}$

\section{Data analysis}

Differences for each data set (metals concentration in the larvae of insects of the three streams) were tested by the Mann-Whitney test. We analyzed significant differences in the concentration of metals between the two trophic levels (collectors and predators). All differences were considered significant if $\mathrm{p}<0.05$. The Mann-Whitney analysis was calculated by using the GraphPad InStat Program (Version 3.00).

\section{RESULTS}

\section{Organic matter content}

Organic matter content of the sediment was low in the three studied streams. Values varied from 5.0 to $20 \%$ in the streams. The highest value was detected in the Água Sumida stream (S1) and the lowest one was observed in the São João stream (S2). Água Preta stream (S3) exhibited values varying from 6 to $15 \%$. Detailed information about these results can be found in reference 7 .

\section{Metal concentration in the sediments}

Cadmium was not detected in the sediment of the streams. In general, iron and aluminum were detected at high concentrations in the sediments of the three streams. Chromium and zinc were detected at low concentrations. In the Água Sumida stream (S1) metal concentrations decreased in the order $\mathrm{Fe}>\mathrm{Al}>\mathrm{Mn}>\mathrm{Cu}>\mathrm{Zn}>\mathrm{Mg}>\mathrm{Cr}$. In the São João stream (S2) the values decreased in the order $\mathrm{Fe}>\mathrm{Al}>\mathrm{Cu}>\mathrm{Mg}>\mathrm{Mn}>\mathrm{Zn}>\mathrm{Cr}$ and in Água Preta stream (S3) decreased in the order $\mathrm{Fe}>\mathrm{Al}>\mathrm{Mg}>\mathrm{Cu}>\mathrm{Mn}>\mathrm{Zn}>\mathrm{Cr}$. The $\mathrm{S} 1$ stream presented higher concentrations of metals than stream S2. Stream S3 presented lower concentrations of metals than streams S1 and S2 (Figure 1).

Copper was detected in the three streams. The highest values of copper were detected in the Água Sumida stream (S1) at a concentration of about $0.060 \mathrm{mg} \mathrm{g}^{-1}$ (Figure 1). Iron exhibited high concentrations in $\mathrm{S} 1$ and $\mathrm{S} 2$ streams. Iron varied from $5.000 \mathrm{mg} \mathrm{g}^{-1}$ in the Água Sumida stream (S1) to $0.265 \mathrm{mg} \mathrm{g}^{-1}$ in the Água Preta stream (S3). Chromium was detected in the $\mathrm{S} 1$ and $\mathrm{S} 2$ streams and it was not detected in S3. Aluminum was detected in the three streams, with highest value detected in the Água Sumida stream (S1), with $0.539 \mathrm{mg} \mathrm{g}^{-1}$. Zinc was detected in all streams. Zinc concentrations varied from $0.060 \mathrm{mg} \mathrm{g}^{-1}$ in the Água Sumida stream (S1) to $0.004 \mathrm{mg} \mathrm{g}^{-1}$ in the Água Preta stream (S3). Magnesium was detected in all streams and varied from 0.052 to $0.025 \mathrm{mg} \mathrm{g}^{-1}$ while $\mathrm{Mn}$ varied from 0.094 to $0.016 \mathrm{mg} \mathrm{g}^{-1}$.

\section{Metal concentrations in the aquatic insects}

As occurred in the sediments, Cd was not detected in the larvae of the insects. In general, the larvae of aquatic insects presented a similar 


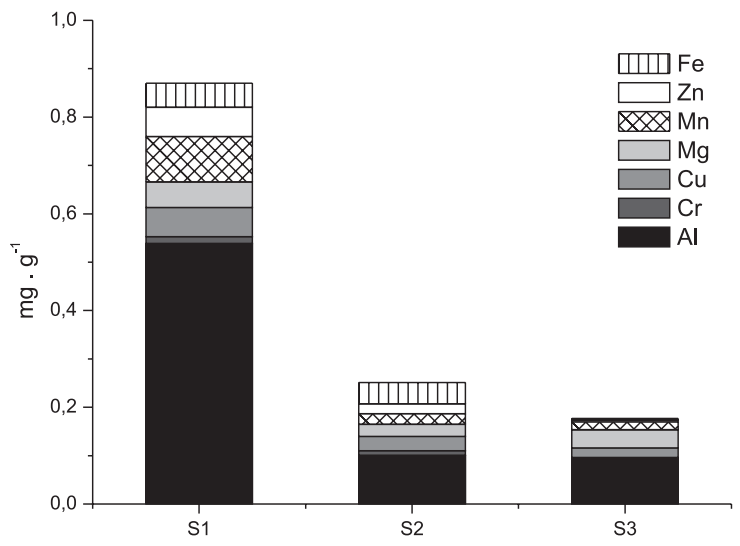

Figure 1. Mean values of metal concentrations determined in sediments from the three sampling sites. Legends as Table 1. Concentrations of Fe are divided by 100

pattern of metal concentrations as those of the sediments. Metals in high concentrations in the sediments, as $\mathrm{Fe}$ and $\mathrm{Al}$ in $\mathrm{S} 1$ and $\mathrm{S} 2$, were highly bioaccumulated in the insects (Figure 2).

Nine species of aquatic insects were collected. They were identified as the collector species Chironomus latistilus and Chironomus detriticola (Chironomidae, Diptera) and the predator species were identified as Dasythemis sp., Erythemis sp., Erythrodiplax sp., Miathyria sp., Dythemis sp., Micrathyria sp. and Tramea sp. (Libellulidae, Odonata).

In Água Sumida stream (S1), the species Chironomus detriticola, Dasythemis sp. and Erythemis sp. were analyzed. With the exception of Al, which was most accumulated by Dasythemis sp, the larvae of Chironomus detriticola accumulate more metals than Dasythemis sp. and Erythemis sp. Dasythemis sp. accumulate more $\mathrm{Al}, \mathrm{Cr}, \mathrm{Cu}, \mathrm{Fe}$, $\mathrm{Mg}, \mathrm{Mn}, \mathrm{Zn}$ than Erythemis sp. (Figure 2).

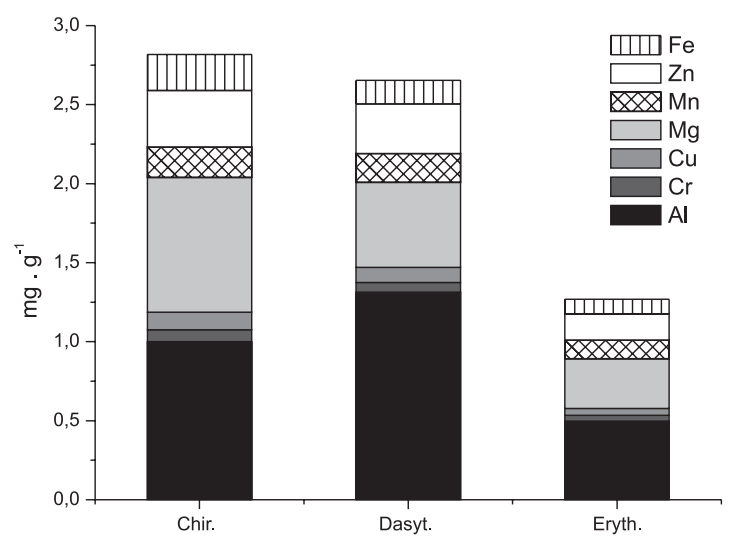

Figure 2. Mean values of metal concentrations detected in the aquatic insects from Água Sumida (S1) stream. Chir. = Chironomus detriticola; Dasy. = Dasythemis sp.; Eryth. $=$ Erythemis sp. Concentrations of Fe are divided by 100

In São João stream (S2), the species Chironomus latistilus, Dasythemis sp. and Erythrodiplax sp. were analyzed. C. latistilus accumulate more metal types than Dasythemis sp. and Erythrodiplax sp. Among the predator species, larvae of Erythrodiplax sp. accumulate high amounts of $\mathrm{Al}, \mathrm{Cr}, \mathrm{Cu}, \mathrm{Fe}$ and $\mathrm{Zn}$, while Dasythemis sp. accumulate high amounts of $\mathrm{Mg}$ and $\mathrm{Mn}$ (Figure 3).

In Água Preta stream (S3), the species Chironomus latistilus, Dythemis sp., Miathyria sp., Micrathyria sp., Erythrodiplax sp. and Tramea sp. were studied. The species Dythemis sp. and Erythrodiplax sp. were excluded from the analyses because of the low biomass

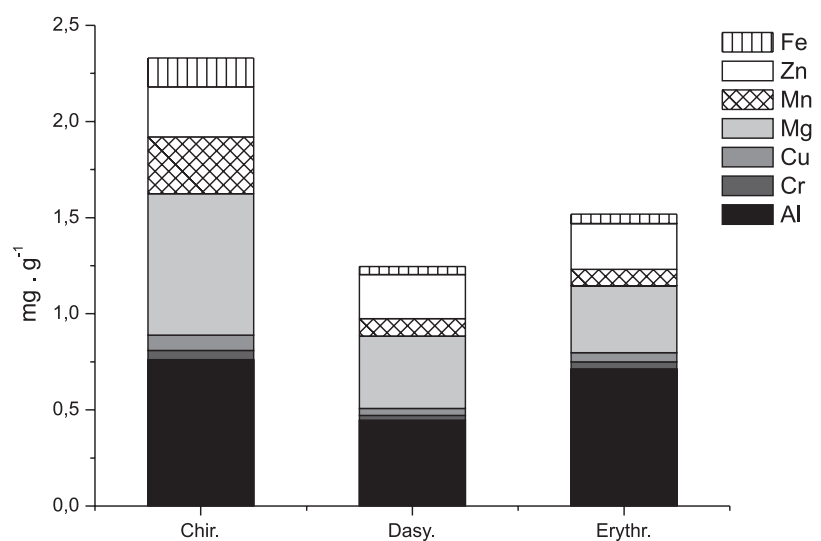

Figure 3. Mean values of metal concentrations detected in the aquatic insects from São João $($ S2) stream. Chir. = Chironomus latistilus; Dasyt. = Dasythemis sp.; Erythr. = Erythrodiplax sp. Concentrations of Fe are divided by 100

collected. Chironomus latistilus accumulate more Fe than Miathyria sp., Micrathyria sp. and Tramea sp. Larvae of Tramea sp. accumulate more $\mathrm{Al}, \mathrm{Cu}, \mathrm{Mg}$ and $\mathrm{Zn}$ than the other species. Chromium and manganese were mostly accumulate by Micrathyria sp. (Figure 4). Detailed information about these results is shown in Figures 2, 3 and 4.

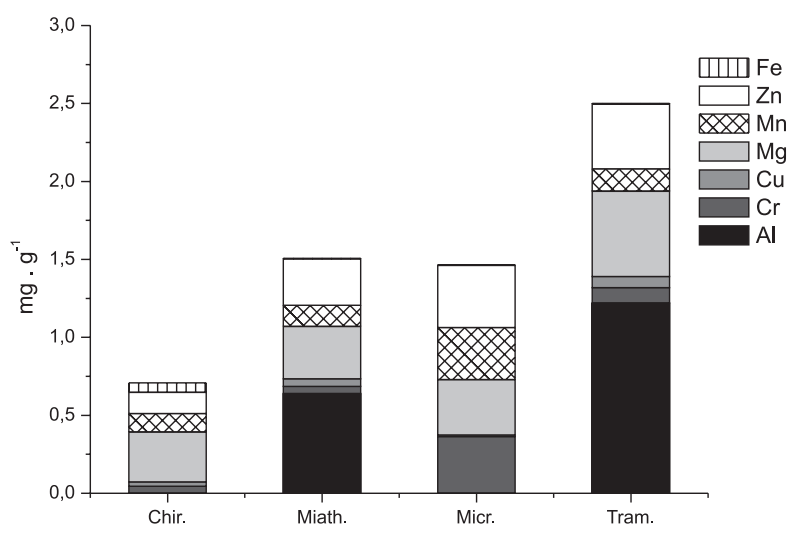

Figure 4. Mean values of metal concentrations detected in the aquatic insects from Água Preta (S3) stream. Chir. = Chironomus latistilus; Miath. $=$ Miathyria sp.; Micr. $=$ Micrathyria sp.; Tram. $=$ Tramea sp. Concentrations of Fe are divided by 100

\section{Data analysis}

The Mann-Whitney test, applied for metal concentrations in the insects of each stream, pointed to significant differences in the bioaccumulation of metals between the collectors and predators. Although, for each metal in each stream, different patterns were observed.

For the S1 stream, the result of the test points that the collector species Chironomus detriticola absorbed higher concentrations of $\mathrm{Cr}$, $\mathrm{Cu} \mathrm{Mg}, \mathrm{Mn}$ and $\mathrm{Fe}$ than the predator species $(\mathrm{p}<0.05)$. Differences were not significant by $\mathrm{Al}$ and $\mathrm{Zn}$. Similarly, in the $\mathrm{S} 2$ stream, Chironomus latistilus, collector species, absorbed higher concentrations of $\mathrm{Cr}, \mathrm{Cu}, \mathrm{Mg}, \mathrm{Mn}$ and $\mathrm{Fe}$ than the predator species $(\mathrm{p}<0.05)$. However, for the $\mathrm{S} 3$ stream, $\mathrm{Al}, \mathrm{Cr}, \mathrm{Cu}, \mathrm{Mg}$, and $\mathrm{Mn}$ were absorbed in the same concentrations between the collector specie Chironomus latistilus and the other predators species, with significant differences by $\mathrm{Zn}$ and $\mathrm{Fe}$.

\section{DISCUSSION}

In the present study, metal concentrations in the larvae of aquatic insects showed differences in accordance to the sediment contamination 
of each stream. When the sediments contamination was high, the insects presented high concentration of metals. All streams analyzed presented higher concentrations of metals in the sediments and in the larvae of Odonata, when compared to forested streams in the State of São Paulo. ${ }^{7,27-29}$ Metals detected in the sediments and in the insects are widely used in several fertilizers in sugar cane cultivation, in addition to NPK fertilizers as source of micronutrients. ${ }^{1}$ The low values of organic matter detected in the sediments and the homogeneous substrate (sand substrates) of the three streams suggest that these variables did not influence in the concentrations of the metals of the sediment and in the aquatic insects.

Cadmium was the unique non-detected metal in aquatic sediments and in the insects of the three streams. Cadmium is a non essential metal and the characterization of cadmium inputs in aquatic systems is incomplete, ${ }^{13}$ but the manufacture of cadmium-containing products (like batteries) accounts for its largest discharge, followed by phosphate fertilizers. ${ }^{30}$ Some studies have demonstrated that cadmium, in high concentrations in the aquatic environment, causes changes in the growth of some insects, as larvae of Chironomus riparius. ${ }^{31}$ Some researchers as ${ }^{32}$ studying in forested and in impacted streams, pointed that aquatic insetcs as mayflies accumulate higher concentrations of $\mathrm{Cd}$ than caddisflies and stoneflies.

Our results points that, iron was found in high concentrations in all streams. Iron is generally related to the geologic formation of the region. In the present work, the results confirm that the region studied is rich in iron. ${ }^{33}$ The high concentration of iron in the sediments of the $\mathrm{S} 1, \mathrm{~S} 2$ and $\mathrm{S} 3$ streams appeared to cause high bioaccumulation in the aquatic insects, especially in the Chironomus species (benthic organism). Aluminum, detected in high concentrations in the sediments of the S1, S2 and S3 streams appeared to be correlated with the high concentrations detected in the aquatic insects, although, with high values observed by Odonata species.

Other studies have also demonstrated the patterns of bioaccumulation of metals by different species of insects. ${ }^{34}$ In the referred study, the authors have demonstrated that the predatory dragonfly larvae seem to be good in detecting differences in iron, manganese, zinc and cadmium in the environment when compared with other predatory insects as waterstriders and ants. These data was confirmed by Corbi et al. ${ }^{7}$ who pointed Odonata larvae as good indicators of metals pollution. Our results suggest that dragonfly larvae are inefficient in accumulating high concentrations of metal from the sediments when compared with the Chironomus larvae (for S1 and S2 streams), a benthic and collector animal, or that Odonata larvae, is efficient in getting rid of it. The data also points that their capacity to accumulate metals differs and further studies are needed for detecting the efficiency of different insects groups to accumulate different metals.

Some researchers found that filter-feeder species, as Mollusks, accumulate more $\mathrm{Mn}, \mathrm{Cu}, \mathrm{Zn}$ and $\mathrm{Pb}$ than Chironomidae species, (not analyzed in Chironomus species) ${ }^{18}$ and some metals, appeared to be accumulated in the upper trophic levels as fishes, reptiles, birds, mammals and other organisms. ${ }^{32,35}$ Although predator species can accumulate high concentrations of metals, our results point that, depending on the sediments contamination, the collector organisms as Chironomus larvae, because of their close association with the sediments (benthic organisms) and functional feeding group, accumulate higher concentrations of metals than other groups of aquatic insects. The results also suggest that, with low sediment contamination, as occurred in the $\mathrm{S} 3$ stream, predator species accumulate metals in high concentrations, probably by food ingestion, composed of different aquatic organisms.

We also can conclude that the aquatic insects can be considered good bioindicators of the metals contamination by fertilizers in streams near to the sugar cane cultivation, as in the three streams, the insects were contaminated. Moreover, some insects, such as Chirono- mus, can be used as good indicators of the sediments contamination, although other aquatic insects as Odonata larvae appeared to be good bioindicators of general contamination. ${ }^{7}$

It is well known that high metal concentrations in aquatic ecosystems lead to a reduction of macroinvertebrate richness and abundance. ${ }^{15,20,36-39}$ In Brazilian streams, Chironomus and Odonata larvae can survive even in sites with very low environmental quality because they are tolerant to many disturbances.,.$^{20,40,41}$ Our results also show that it is possible to analyze metal concentrations in these aquatic macroinvertebrates even when the community is very poor, as occurs in sites near to the sugar cane culture

\section{CONCLUSIONS}

The higher concentrations of metals detected in the collectors species than in the predators species (except for S3 stream) points to the necessity to obtain more knowledge about the biology of the aquatic organisms. Although in the low trophic position (collectors animals), the benthic habitat of the Chironomus species, living closer to the sediment, turns possible the high bioaccumulation of metals found in this aquatic compartment. Even though, the low sediment contamination causes high bioaccumulation in predators species. These aquatic organisms can be used, by different ways, as an important tool for monitoring metal contaminations in streams located in areas with sugar cane cultivation or other agricultural activity.

\section{ACKNOWLEDGEMENTS}

We would like to thank Dr. P. P. Corbi, Dra. V. C. Corbi and Prof. L. O. I. de Souza, for their fruitful suggestions. Financial support: FAPESP (Fundação de Amparo à Pesquisa do Estado de São Paulo), proc. $n^{\circ} 06 / 61400-2$.

\section{REFERENCES}

1. Angelotti-Netto, A.; Crestana, S.; De Oliveira, S. C.; Barbosa, R. V. R; Bacia Hidrográfica, Rima Editora, São Carlos, 2004.

2. Corbi, J. J.; Trivinho-Strixino, S.; dos Santos, A.; Del Grande, M.; Quim. Nova 2006, 29, 61.

3. Du, J. Z.; Mu, H. D.; Song, H. Q.; Yan, S. P.; Gu, Y. J.; Zhang, J.; Water, Air, Soil Pollut. 2008, 190, 343.

4. Haus, N.; Zimmermann, S.; Wiegand, J.; Sures, B.; Chemosphere 2007, 66,619 .

5. Notten, M. J. M.; Oosthoek, A. J. P.; Rozema, J.; Aerts, R.; Envir. Pollut. 2005, 138, 178.

6. Schroder, N.; PhD Thesis, Wageningen University, Wageningen, 2005.

7. Corbi, J. J.; Trivinho-Strixino, S.; Dos Santos, A.; Water, Air, Soil Pollut. 2008, 195, 325 .

8. Dudgeon, D.; Hydrobiologia 1989, 179, 183.

9. Nery, M. S.; Dissertação de Mestrado, Universidade de São Paulo, Brasil, 2000.

10. Martins, S. J.; Recuperação de Matas Ciliares, $1^{\mathrm{a}}$ ed., Ed. Conceito: Viçosa, 2001.

11. Primavesi, O.; Freitas, A. R.; Primavesi, A. C.; Oliveira, H. T.; Braz. Arch. Biol. Technol. 2002, 45, 209.

12. Zhou, Q.; Zhang, J.; Fu, J.; Shi, J.; Jiang, G.; Anal. Chim. Acta 2008, $606,135$.

13. Mertz, W.; Trace Elements in Human and Animal Nutrition, $5^{\text {th }}$ ed., Academic Press: London, 1986.

14. Ip, C. C. M.; Li, X. D.; Zhang, G.; Wai, O. W. H.; Li, Y. S.; Environ. Pollut. 2007, 147, 311.

15. Clements, W. H.; Community responses of stream organisms to heavy metals, Univ. Press: Colorado, 1991. 
16. Mason, R. P.; Laporte, J. M.; Andres, S.; Arch. Environ. Contam. Toxicol. 2000, 38, 283.

17. Duran, M.; Kara, Y.; Akyildiz, G. K.; Ozdemir, A.; Bull. Environ. Contam. Toxicol. 2007, 78, 395.

18. Pourang, N.; Hydrobiologia 1996, 331, 53.

19. Sola, C.; Prat, N.; Sci. Total Environ. 2006, 359, 221.

20. Corbi J. J.; Trivinho-Strixino, S.; Braz. Arch. Biol. Technol. 2008, 51, 769.

21. Hare, L.; Campbell, P. G. C.; Freshwater Biol. 1992, l27, 13.

22. Merrit, R. W.; Cummins, K. W.; An Introduction to Aquatic Insects of North America, Kendall-hunt: Dubuque, 1996.

23. Rocha, J. C.; Rosa, A. H.; Substâncias Húmicas Aquáticas: Interação com Espécies Metálicas, Ed. Unesp: São Paulo, 2003.

24. Tschöpel, P.; Kotz, L.; Shulz, W.; Veber, M.; Tölg, G.; Fresenius J. Anal. Chem. 1980, 302, 1.

25. De Paula, F. C. F.; Mozeto, A. A.; Appl. Geochem. 2001, 16, 1139.

26. Maitland, P. S.; Arch Hydrobiol. 1979, 5, 98.

27. Lima, N. R. W.; Acta Limnol. Bras. 1990, 3, 1001.

28. Santos, A.; Dissertação de Mestrado, Universidade de São Paulo. Brasil, 1999.
29. CETESB; Relatório de estebelecimento de valores orientadores para solos e águas subterrâneas no Estado de São Paulo, CETESB: São Paulo, 2000.

30. Kostial, K. In Trace elements in human and animal nutrition; Mertz, W., ed.; Academic Press, Inc.: London, 1986, cap. 8.

31. Postma, J. F.; Kyed, M.; Admiraal, W.; Hydrobiologia 1995, 315, 159.

32. Wayland, M.; Crosley, R.; Environ. Contam. Toxicol. 2006, 50, 511.

33. Nummelin, M.; Lodenius, M.; Tulisalo, E.; Hirvonen, H.; Alanko, T.; Environ. Pollut. 2007, 145, 339.

34. Barreto, A. dos S.; Tese de Doutorado, Universidade de São Paulo, Brasil, 1999.

35. Warren, L. A.; Tessier, A.; Hare, L.; Limnol. Oceanogr. 1998, 43, 1442.

36. Norris, R. H.; Lake, P. S.; Swain, R.; Aust. J. Mar. Freshw. Res. 1982, 33,789 .

37. Mori, C.; Orsini, A.; Migon, C.; Hydrobiologia 1999, 392, 73.

38. Hirst, H.; Jüttner, I.; Ormerod, S. J.; Freshwater Biol. 2002, 47, 1752.

39. Ometo, J. P. H. B.; Martinelli, L. A.; Ballister, M. V.; Gessner, A.; Krische, A. V.; Victoria, R. L.; Freshwater Biol. 2000, 44, 327.

40. Roque, F. O.; Trivinho-Strixino, S.; Acta Limnol Bras. 2001, 13, 69.

41. Ferreira-Peruquetti, P.; Fonseca-Gessner, A. A.; Rev Bras Zool. 2003, 20, 219. 